\title{
La República insospechada. De cómo la prensa madrileña no supo predecir la fulminante liquidación de la Monarquía de Alfonso XIII
}

\author{
Vicente Clavero MartíN \\ Universidad Complutense de Madrid \\ viclaver@ucm.es
}

Recibido: 18 de diciembre de 2014

Aceptado: 5 de junio de 2015

\section{Resumen}

Ninguno de los grandes diarios de Madrid fue capaz de intuir siquiera en sus ediciones del 14 de abril de 1931 que ese mismo día sería proclamada la Segunda República en España. He ahí el hallazgo más sorprendente de la investigación a la que se refiere el presente artículo, que analiza las posiciones editoriales que mantuvieron los siete rotativos de mayor tirada (tres monárquicos y cuatro republicanos) desde la dimisión de Primo de Rivera en enero de 1930 hasta la caída de Alfonso XIII.

Palabras clave: Segunda República, 14 de abril, ABC, El Debate, Ahora, El Sol, El Liberal, Heraldo de Madrid, La Voz.

\section{The nexpected Republic. That's how Madrid press did not know how to predict the sudden fall of Alfonso XIII's Monarchy}

\begin{abstract}
None of Madrid major newspapers was able to even perceive intuitively in their editions of April 14, 1931 that on the same day the Second Republic would be proclaimed in Spain. Here we have the most amazing finding of the research to which this article refers to, which analyzes the editorial positions held by the seven newspapers of widest distribution (three monarchists and four republicans) since Primo de Rivera's resignation in January 1930 to the fall of Alfonso XIII.

Keywords: Second Spanish Republic, April 14, ABC, El Debate, Ahora, El Sol, El Liberal, Heraldo de Madrid, La Voz.

\section{Referencia normalizada}

CLAVERO MARTÍN, Vicente (2015): "La República insospechada. De cómo la prensa madrileña no supo predecir la fulminante liquidación de la Monarquía de Alfonso XIII". Estudios sobre el Mensaje Periodístico. Vol. 21, Núm. 2 (julio-diciembre), págs.: 1003-1016. Madrid, Servicio de Publicaciones de la Universidad Complutense.
\end{abstract}

Sumario: 1. Introducción. 2. Objetivos, metodología y fuentes. 3. Resultados; 3.1. La demanda de un proceso constituyente; 3.2. El boicot a Berenguer; 3.3. La interpretación de las elecciones del 12 de abril; 3.4. El recibimiento a la República. 4. Conclusiones. 5. Referencias bibliográficas. 6. Referencias hemerográficas.

\section{Introducción}

La Dictadura de Primo de Rivera produjo una expansión del republicanismo, que en los compases iniciales del siglo XX sólo profesaba en España una minoría relativamente pequeña de la gente interesada en el progreso y la reforma (Payne, 1995: 39). A un así, la Monarquía podría haberse salvado si, tras el régimen de excepción, se hubiera procedido a la inmediata reposición de las garantías constitucionales en suspenso desde septiembre de 1923. Sin embargo, Alfonso XIII nombró presidente del Consejo de Ministros a otro militar, el general Dámaso Berenguer, que gobernó por decreto durante un año y sólo al final de su mandato accedió a convocar elecciones. 
Para entonces, el rey se había granjeado la desconfianza incluso de una parte significativa de la clase conservadora, que dudaba de su capacidad para conjurar el peligro de una revolución social (Carr, 1970: 577). Por ese y otros motivos, carecía también del apoyo incondicional de algunos soportes tradicionales del régimen, como los poderes económicos, la Iglesia y el Ejército (Juliá, 2007:79). A finales de 1930, tales fuerzas habían llegado al convencimiento de que la forma de Gobierno era secundaria a efectos de mantener sus privilegios y estaban dispuestas a ensayar una república burguesa (Robinson, 1974: 41).

Todo ello derivó en un sentimiento antimonárquico que se puso de manifiesto en las municipales del 12 de abril de 1931, las primeras desde el golpe de Primo de Rivera. El descalabro de las candidaturas dinásticas fue de tal magnitud que, sólo dos días después, Alfonso XIII tuvo que poner tierra de por medio, dejando el campo libre a sus adversarios. Sin embargo, pocos sospecharon hasta muy pocas horas antes que la Segunda República sería proclamada de una forma tan rápida. El 13 por la noche, el propio rey se sentía todavía con fuerzas para resistir, según le comunicó a su médico de cámara, el doctor Floristán Aguilar (Cortés Cavanillas, 1933: 210-211). En el otro bando, personajes tan avezados como Francisco Largo Caballero y Fernando de los Ríos pensaban que los frutos de su cosecha en las urnas no podrían recogerse hasta pasado cierto tiempo, cuando se confirmaran en unas elecciones generales (Maura, M., 1962: 147-148). A pie de calle, en fin, los optimistas pronosticaban que, "de allí a un par de meses", el nuevo Ayuntamiento pondría a la Gran Vía el nombre de Avenida de la República, la de Cibeles pasaría a llamarse plaza de los capitanes Galán y García Hernández... Eso era a lo más que se atrevían en vísperas del cambio de régimen (Carabias, 1980: 62-63).

\section{Objetivos, metodología y fuentes}

Si la proclamación de la República cogió por sorpresa al rey, a destacados dirigentes políticos y no digamos ya al común de los ciudadanos, no hay ningún estudio sobre qué ocurrió en el caso de la prensa. Las obras generales no prestan demasiada atención a los posicionamientos editoriales que precedieron a la caída de la Monarquía y, a lo sumo, aportan detalles muy fragmentarios. Es el caso, por ejemplo, de la Historia del periodismo español de Pedro Gómez Aparicio, que narra algunas anécdotas de las que fue testigo en aquellos días por su condición de redactor jefe de El Debate (1981: 242-246). O de la Historia del periodismo en España de María Cruz Seoane y María Dolores Saiz, que en su tercer volumen muestran la acogida que algunos medios dispensaron al nuevo régimen (1996: 35), igual que hace Justino Sinova en $\mathrm{La}$ prensa en la Segunda República española (2006: 24-32). Por su propia naturaleza, las monografías sobre cabeceras concretas tampoco ofrecen una panorámica completa, como puede comprobarse en las que Víctor Olmos dedicó a $A B C$ (2002); José María García Escudero, a El Debate (1983), o la más reciente de Gil Toll sobre Heraldo de Madrid (2013).

Precisamente ese vacío es el que pretende llenar el presente trabajo, en el que se reconstruye el discurso que mantuvo la prensa durante los quince meses escasos transcurridos desde la caída de Primo de Rivera hasta la llegada de la Segunda República. 
¿Qué salidas políticas plantearon los periódicos tras el final de la Dictadura? ¿Supieron sostenerlas? Y, sobre todo, ¿fueron capaces de predecir lo que ocurrió el 14 de abril de 1931? Para averiguarlo se ha recurrido a los siete diarios de mayor tirada en esa fecha: $A B C$, Heraldo de Madrid y Ahora, que superaban los 100.000 ejemplares, y El Debate, El Sol, La Voz y El Liberal, que distribuían entre 50.000 y 100.000 (Checa Godoy, 1989: 28). Tres de ellos eran de clara filiación monárquica: $A B C$, Ahora y El Debate, que reunía también la condición de portavoz de la jerarquía católica. En cambio, las otras cuatro (El Sol, El Liberal, Heraldo de Madrid y La Voz) defendían los postulados republicanos. Pese a sus respectivas derivas ideológicas, los siete eran periódicos de empresa, disfrutaban de una gestión profesionalizada (Sánchez Aranda y Barrera del Barrio, 1992: 205) y pudieron manifestarse con independencia, salvo cuando la censura no les dejó.

El espacio temporal de la investigación abarca desde finales de enero de 1930 hasta el miércoles 15 de abril de 1931. Siempre se han manejado las fuentes originales y, en concreto, las colecciones depositadas en la Biblioteca Nacional y en la Hemeroteca Municipal de Madrid. Gracias al servicio digital de la primera de estas dos instituciones, la consulta on line de los ejemplares de Heraldo de Madrid, El Sol y La Voz ha sido rápida y cómoda. El rastreo de las páginas de Ahora, El Debate y El Liberal se he llevado a cabo in situ en la Hemeroteca Municipal de Madrid aprovechando el correspondiente material microfilmado. El diario que falta, $A B C$, tiene su propia hemeroteca, de fácil acceso a través de Internet. El estudio se circunscribe, con alguna excepción, al ámbito de los editoriales, que no en vano son la voz propia de los periódicos y lo que mejor refleja su intencionalidad ideológica (Santamaría y Casals, 2000: 206). El contenido ha sido analizado desde una doble perspectiva: la sincrónica, para comparar qué dijeron en cada momento, y la diacrónica, para determinar si sus respectivas posturas antes y después de las elecciones guardaban la presumible continuidad ${ }^{1}$.

\section{Resultados}

\subsection{La demanda de un proceso constituyente}

Pese a los desencuentros que ocasionalmente habían tenido con el dictador, $A B C$ (2901-1930, p. 15) y El Debate (29-1-1930, p. 1) despidieron con encendidos elogios a Primo de Rivera tras su dimisión y se felicitaron de la vuelta a la normalidad que Alfonso XIII acababa de encomendar al nuevo presidente, el general Dámaso Berenguer, hasta entonces jefe de la Casa Militar del rey. Los diarios antidinásticos, en cambio, advirtieron de que reavivar las garantías constitucionales era condición necesaria pero no suficiente para que España se sobrepusiera a siete años de régimen de excepción. Según $E l$ Sol, aun desaparecida la Dictadura, el problema político seguía en pie "con idéntica gravedad" y sólo el país, por sí mismo, podía resolverlo (30-01-

1 Esta investigación formó parte de la tesis doctoral del autor, titulada La prensa madrileña ante la llegada de la Segunda República, defendida el 26 de noviembre de 2014 en la Facultad de Ciencias de la Información de la Universidad Complutense de Madrid, bajo la dirección de la profesora Mirta Núñez Díaz-Balart. 
1930, p. 1). Con menos rodeos, $L a$ Voz aseguraba que la misión de Berenguer no podía ser otra que preparar el terreno para que los ciudadanos se pronunciaran acerca de los problemas que afectaban "al presente y al futuro de la patria". Lo cual no sería posible si no se restablecían las libertades de imprenta, reunión, asociación y manifestación, si no se constituían los municipios y las diputaciones con arreglo a los dictados del sufragio universal, si no se convocaban elecciones generales y si esas elecciones generales no se celebraban dentro de "un escrupuloso respeto al derecho de todos los ciudadanos" (30-01-1930, p. 1).

Los otros dos periódicos republicanos compartían esa opinión. Heraldo de Madrid sostenía que Berenguer debía liquidar la obra de la Dictadura, "empalmándola con la legalidad anterior", para que la historia de España pudiera seguir "desembarazadamente" su marcha, después del largo paréntesis del que acababa de salir. Pero no bastaba con recuperar la Constitución del 76, cuya falta de eficacia había quedado "bien patente". Eso sólo podía ser el punto de partida para luego "defenderla, enmendarla o impugnarla íntegramente" (31-01-1930, p. 1). El Liberal pensaba, además, que no se debía perder el tiempo: "Hay quien aconseja al jefe de Gobierno que proceda con mucha parsimonia, que devuelva a España sus libertades, no enseguida y de una vez, sino dentro de algún tiempo y homeopáticamente". Frente a ello, El Liberal exigía que la devolución de las libertades públicas fuese "inmediata y total" (30-01-1930, p. 1).

El presidente del Gobierno, sin embargo, remoloneó durante meses, para desesperación de quienes clamaban por una catarsis política, magistralmente expresada por José Ortega y Gasset en El error Berenguer, que apareció en la primera página de El Sol el 15 de noviembre de 1930. Este histórico artículo admitía que el levantamiento de Primo de Rivera pudo haber sido inevitable, pero ni siquiera en tal caso estaba justificada su "creciente y monumental iniuria", su "crimen de lesa patria, de lesa historia, de lesa dignidad". Si aceptó obligado la Dictadura, al terminar ésta el rey debería haberle dicho al pueblo: "Hemos padecido una incalculable desdicha. La normalidad que constituía la unión civil de los españoles se ha roto. La continuidad de la historia legal se ha quebrado. No existe el Estado español. ¡Españoles: reconstruid vuestro Estado!” En lugar de eso, "que era lo congruente con la desastrosa situación", Alfonso XIII había hecho todo lo contrario para "una vez más salir del paso", escogiendo a un general que llevara a cabo la política del "aquí no ha pasado nada". "Ése es el error Berenguer, de que la historia hablará. Y como es irremediablemente un error, somos nosotros, y no el régimen mismo; nosotros, gente de la calle, de tres al cuarto y nada revolucionarios, quienes tenemos

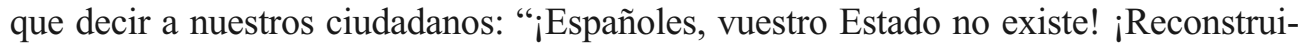
dlo! Delenda est Monarchía” (El Sol, 15-11-1930, p. 1).

\subsection{El boicot a Berenguer}

Berenguer optó finalmente por elecciones a Cortes de carácter ordinario, seguidas de las provinciales y locales; pero su proyecto saltó por los aires debido al retraimiento de la mayoría de las fuerzas políticas, que no veían otra salida a la situación vivida en España desde el 13 de septiembre de 1923 que ir a un proceso constituyente. Ese boicot sentó muy mal a $A B C$ y a El Debate, que dedicaron duros ataques a quienes habían anunciado su propósito de no concurrir a las urnas. Ahora, siempre más templado, 
jugó a la equidistancia en el único editorial que dedicó a la situación política durante aquellos días y que se titulaba Ni Dictadura ni revolución. Según él, había "una masa sana de opinión" que, aun consciente de la necesidad de una transformación profunda, no creía necesario para ello romper completamente con el pasado y lanzarse a una "aventura" cuyas consecuencias eran difíciles de prever. Esa masa de opinión, a la que el periódico aspiraba a servir de cauce, ni se inclinaba por una revolución ni era partidaria de una nueva Dictadura. De ahí que Ahora apostase por una "solución jurídica" que encauzara "las pasiones" y permitiera "una polémica incruenta entre las diversas ideas" (10-02-1931, p. 3).

La prensa de oposición al régimen, que seguía siendo partidaria de dar la voz al pueblo cayese quien cayese, arremetió sin ambages contra los planes electorales de Berenguer. El Sol creía que las Cortes ordinarias sólo servirían para ahondar la división "irreconciliable" de los ciudadanos en "dos bandos" (10-02-1931, p. 1). La Voz aventuraba que, si se mantenía la convocatoria, dentro del nuevo Parlamento estaría "la España caduca, sola en su incomprensión, sola en su egoísmo, sola en su inconsciencia". Fuera, "actuando ciudadanamente", porque no quería morir y se aprestaba para "cumplir su misión histórica", quedaría la otra, que era "la España vital" (10-02-1931, p. 1). Heraldo de Madrid, en fin, terció en la polémica con un editorial tajante en el que denunciaba que Primo de Rivera había metido a España en un laberinto que no se podía arreglar con componendas, porque los ciudadanos querían una salida diáfana, sin posibilidad de retroceso (10-02-1931, p. 1).

La posición de Berenguer se hizo insostenible y el 18 de febrero de 1931, después de varios intentos fallidos, Alfonso XIII acabó propiciando un Gobierno de concentración monárquica presidido por el almirante Juan Bautista Aznar, capitán general de la Armada. Éste anunció tras su nombramiento que el proceso hacia la normalización política sería justo al revés del que había diseñado su predecesor: empezaría con elecciones municipales y culminaría con la de los diputados y senadores, que podrían revisar la obra de la Dictadura y aquellos aspectos de la Constitución de 1976 que fueran necesarios. El cambio desagradó a $A B C$, que el 20 de febrero lo tachó de "lamentable", aunque admitía que era la formula reclamada por buena parte de los partidos y de los periódicos, "los de izquierda con más empeño". Estaba de acuerdo en que la consulta al país urgía, porque en cuanto el pueblo hablara se despejaría la situación y, con las cifras electorales en la mano, quedarían "virtualmente resueltos todos los problemas políticos". Sin embargo, a $A B C$ no le convencían los motivos que habían llevado a revocar el calendario concebido por Berenguer, porque el sentido del voto sería el mismo, "con el mismo espíritu y la misma calidad", y daría "la misma sentencia" (20-02-1931, p. 17).

El Debate, por el contrario, consideraba que el anunciado por Aznar era el orden lógico. En lo que no estaba de acuerdo era en que las futuras Cortes fueran ordinarias pero tuvieran capacidad de modificar la Constitución, salvo que con ello sólo se persiguiera allanar "el camino de retorno a quienes se fueron a un voluntario ostracismo", en clara referencia al retraimiento de los partidos republicanos contra la convocatoria de Berenguer (20-02-1931, p. 1). Mientras tanto, en la otra orilla mediática se insistía en la conveniencia de unas elecciones constituyentes y en que su convocatoria tuviera un carácter 
"especial", porque no era lo mismo votar a un diputado para elaborar una Constitución que para defender los intereses de un distrito (El Sol, 21-02-1931, p. 1)

\subsection{La interpretación de las elecciones del 12 de abril}

El pleito electoral quedó zanjado a mediados de marzo con el anuncio oficial de un calendario que incluía tres etapas: municipales el 12 de abril, provinciales el 3 de mayo y generales el 7 y el 14 de este último mes. El Gobierno confirmó que las futuras Cortes estarían facultadas para tocar la Constitución y revisar toda la obra legislativa de la Dictadura y prometió que el proceso sería limpio ("sincero", en la terminología de la época). Sin embargo, enseguida se planteó si, después de casi ocho años de silencio democrático, la primera de esas consultas tendría en el fondo un alcance plebiscitario. Los grandes diarios monárquicos no parecían abrigar ninguna duda antes de que se celebrara. Es más, los tres hicieron notorios esfuerzos para convencer a sus lectores de que no se iba a elegir sólo a unos millares de concejales. Como mínimo - decía $A B C$ - estaban en juego también el principio de autoridad y el imperio de la ley (1104-1931, p. 25). El Debate abundaba en esa idea: "He aquí el dilema que se presenta hoy al elector de Madrid: o votar a la Monarquía y con ella el orden social y la administración en el municipio; o votar a la República y con ella la revolución y la conversión del Ayuntamiento en el club demagógico" (11-04-1931, p. 1). Ahora venía a decir lo mismo, aunque con distintas palabras: "Hay una candidatura que postula el mantenimiento del régimen - señalaba el día 12- y otra que considera indispensable la revolución. Sabemos lo que es el régimen. ¿Sabe alguien lo que es la revolución?" De ahí que la victoria monárquica fuese la única garantía de que España, "con sus vicios y sus virtudes, con sus glorias y sus tristezas, con el respeto a sus tradiciones y a su religión", subsistiría como "entidad racional en el concierto de los pueblos" (12-041931, p. 3).

En el bando republicano también tenían clara la interpretación que debía darse a las municipales, según quedó reflejado, por ejemplo, en el editorial de La Voz titulado con un imperativo ;Cúmplase la voluntad nacional! Aseguraba éste que, pese a tratarse de unas elecciones teóricamente administrativas, por fin iba a conocerse la evolución que había experimentado la opinión pública "a través de los años de silencio forzoso y de esclavitud ominosa" de la Dictadura. La Voz no ocultaba su deseo de que los resultados abocaran "a una situación premonitoria de Cortes constituyentes", que debían ser "expresión de la voluntad colectiva", para que volviera la paz a España y que el país se deslizara por los rieles que habían de conducirla "a la libertad y a la justicia" (11-04-1931, p. 1). El Liberal cedió la palabra el 11 de abril a uno de los dirigentes antidinásticos, Marcelino Domingo, que firmaba ese día un descarnado artículo en la primera página. Se titulaba Por qué se debe votar por la República y por qué no se puede votar por la Monarquía, y estaba expresamente dirigido a los conservadores, a los liberales, a los católicos y a quienes, sin ideales, sólo pensaban "egoístamente" en la seguridad y defensa de sus propios intereses. Ninguno de ellos tenía motivos -según Domingo- para sostener al régimen, que en todo caso podría ser apoyado por los que le debieran su cargo o su sueldo o por "el residuo de las oligarquía y el caciquismo" (11-04-1931, p. 1). 
Las municipales se saldaron con un notable éxito de las candidaturas republicanosocialistas $^{2}$, del que pudieron hacerse eco el día 13 los diarios vespertinos (Heraldo de Madrid y La Voz), no así los de la mañana, que no salían a la calle los lunes debido al preceptivo descanso dominical. Sin embargo, ninguno de los siete iría más allá de reclamar que se diera cauce institucional a la voluntad expresa de la opinión pública, ni dio muestras de sospechar lo que estaba a punto de suceder. El desenlace de las elecciones -admitía Heraldo de Madrid- había superado "todos los cálculos y a todas las previsiones, aun las del optimismo más exaltado". Incluso en "regiones dominadas de siempre por una fuerza caciquil que se creía invencible" se había despertado "con vigor insospechado" una conciencia de "los derechos y virtudes ciudadanas, un anhelo de reivindicación, un ansia de dignificarse y libertarse". Esas regiones, "con su actitud viril de independencia", se habían sacudido "el yugo secular", proporcionando "una derrota a domicilio a los genuinos representantes del más genuino caciquismo español”. Heraldo de Madrid añadía que, por la alta participación registrada, se podía conceder a la consulta "el carácter plebiscitario que desde su anuncio le adjudicaron las izquierdas", y con un resultado, además, que no admitía dudas, pues ocho de cada diez electores se había pronunciado por un cambio en la forma de Gobierno (13-041931, p. 1).

La Voz tampoco albergada dudas sobre lo ocurrido: "Se iba a decidir la secular contienda entre la España pétrea y faraónica, puesta como un monolito en el Occidente europeo, y la España viva, enérgica, sana y optimista, que no se resigna a ser una excepción mundial". Y los representantes de esta última habían cosechado una victoria aplastante en casi todas las capitales de provincia y en muchas ciudades importantes. Después de coincidir con Heraldo de Madrid en que había sido un plebiscito en toda regla, $L a \mathrm{Voz}$ lanzaba su propuesta para satisfacer los deseos expresados en las urnas por el pueblo, que vista ahora puede antojarse demasiado tibia: "No hay más que un camino: el que lleva a las Cortes constituyentes con cámara única, convocadas por un Gobierno libre de compromisos altos, asistido de todas las garantías y que dé al país la seguridad absoluta de que su voluntad, libremente expresada, será acatada sin duda ni mentales reservas". Sólo así se podía salir de la situación creada "sin violencias, sin luchas duras y amargas". "Sólo así la mudanza institucional inexorablemente iniciada podrá consumarse pacíficamente. Pero urge apresurarse. Hoy todavía es tiempo, quizás mañana no lo sería" (13-04-1931, p. 1).

2 Sobre el resultado de aquellas elecciones, el periodista e historiador Isabelo Herreros publicó un esclarecedor artículo en el diario Público el 16 de abril de 2011. A partir de datos oficiales, aseguraba en él que, de las 50.688 actas que estaban en juego el 12 de abril, los republicanos obtuvieron 20.428; los socialistas, 3.926; los comunistas, 57, y los monárquicos, 12.970. Para otras formaciones fueron 9.155 y no consta la filiación de 4.132 concejales. Aparte de esto, hubo 29.804 puestos que se cubrieron sin votación, de conformidad con lo establecido en el artículo 29 de la Constitución, al haberse presentado una sola candidatura. Esos puestos, correspondientes a localidades muy pequeñas, sí se los adjudicaron mayoritariamente los monárquicos (Herreros: 1931, p. 5). 
El mismo día 14, por el contrario, $A B C$ rechazó con total desparpajo que las elecciones hubieran proporcionado un triunfo ni numérico ni legal a la coalición republicanosocialista. Si había obtenido más votos de lo que se esperaba era como consecuencia de una campaña basada en "la mentira contra sus adversarios, la difamación y la calumnia contra el rey". $A B C$ era partidario, por ello, de no sacar de quicio los resultados del domingo anterior, que habían acentuado la crisis en que se hallaba el país desde la caída de la Dictadura y a la que, en su opinión, sólo las Cortes podían dar una solución legítima. "Lo demás, todo lo que se intente y se haga sin la decisión del Parlamento, cualquier empeño de resolver la crisis ilegalmente y de imponer hechos consumados a la soberanía nacional -avisaba-, sería la discordia y el desorden" (14-04-1931, p. 23).

Más clamorosa aún fue la falta de coherencia de El Debate. Cuarenta y ocho horas después de haber defendido el carácter plebiscitario de las municipales, el periódico no tenía el menor empacho en negárselo: "Las elecciones de anteayer no son un plebiscito. Un plebiscito es una consulta al pueblo; una pregunta que el pueblo contesta. Y al pueblo español no se le preguntó anteayer si quiere que el Rey abdique". El bloque antidinástico -agregaba- podía estar satisfecho de su triunfo, pero no decir que España había decidido cambiar su forma de Gobierno. La propuesta de El Debate era meridiana: "Que se pregunte a la nación con rapidez si quiere Monarquía o República; que se convoque a Cortes constituyentes; que a una u otra convocatoria preceda un manifiesto del Rey al país anunciando su abdicación, si así lo quiere la voluntad de España; que por esos u otros procedimientos, rápidos, sinceros, sin trasnochadas habilidades, se haga la consulta; que la haga un Gobierno respetable, solamente constituido para ese fin". Sólo entonces se podría hablar de la voluntad del país "rectamente" (14-04-1931, p. 1).

Ahora, en cambio, no mostró reservas al admitir el triunfo de los adversarios de Alfonso XIII, dejando al margen pueriles "cubileteos con las estadísticas". "Quizás muchos de los votos que aparecen como republicanos sean más bien votos de protesta contra la Dictadura; quizás hayan imperado en ellos más razones negativas que motivos positivos -señalaba-; pero hay que reconocer que la votación republicana tiene una brillantez que sus adeptos más entusiastas no se hubieran atrevido a esperar". Llevado por la impresión que el desarrollo de las elecciones le había producido, el periódico sugería: "Hoy es un síntoma consolador la disciplina y el orden con que unos y otros han acudido a las urnas en unas elecciones que nada tienen que envidiar a las que puedan haberse celebrado en los países más adelantados. Si esta serenidad y esta disciplina siguen imponiéndose y no salen sueltas y desaforadas por ahí las pasiones, todavía puede ser la jornada del domingo la iniciación de una época nueva en la historia de España" (14-04-1931, p. 3).

Mientras sus colegas de la mañana discutían sobre galgos y podencos, los otros diarios matutinos alertaron del error que supondría cualquier salida a la crisis que no pasara por el reconocimiento de la realidad emanada de las urnas. Inmerso en un cambio de propiedad, que había supuesto el desembarco en el capital de un puñado de amigos de Alfonso XIII, El Sol había mantenido un perfil bajo durante la campaña electoral. Pero en su editorial del día 14, titulado Veredicto, no dudó en señalar de los 
riesgos de una involución: "El Gobierno está en el alto deber de no turbar, con actitudes de las que el decoro esté ausente, esta aceptación con precedentes invocables en la historia [...]. La suerte está echada, y seguir viviendo importa con la dignidad indispensable. El pueblo lo ha exigido. Él es el soberano. Por encima de los acontecimientos, él debe decidir y mandar" (14-04-1931, p. 1).

La cabecera que dio mayor trascendencia al resultado de las elecciones y que exigió con más vehemencia que tuviera efectos políticos inmediatos fue El Liberal. "Nadie puede dudar hoy que España es republicana, que ha triunfado la República", decía el día 14. Por ello, no había más alternativa que la convocatoria de Cortes constituyentes "con todas sus consecuencias, con el natural y lógico desplazamiento de todos los poderes constituidos". A esas Cortes "restauradoras de la libertad" convenía ir sin demora, en cuanto se produjera "el hecho histórico" que esperaba "no ya España, sino el mundo entero": la renuncia del rey. "Las elecciones del domingo -añadía- han dejado libre el solar, tan libre como hubiera podido quedar después de una revolución triunfante" (14-04-1931, p. 1). Probablemente no sabía El Liberal hasta qué punto estaba en lo cierto.

\subsection{El recibimiento a la República}

Pese a no haber sido capaces de predecir su fulminante advenimiento, los grandes diarios de Madrid saludaron la República en unos casos con satisfacción, en otros con respeto y $A B C$, en particular, con un indisimulado desdén ${ }^{3}$. Este periódico lamentaba que el veredicto de las urnas, en las elecciones del domingo anterior, hubiera sido interpretado en clave plebiscitaria, porque la convocatoria no había tenido por objeto revisar la forma de Gobierno. "Sabíamos y decíamos todos que significaba una primera exploración, un antejuicio, que podía modificar, acentuar o retirar las posiciones de la contienda; pero ni monárquicos ni republicanos se hubiesen avenido a liquidar en una elecciones de ayuntamientos el problema constituyente". A pesar de ello, $A B C$ justificaba la decisión de Alfonso XIII de marcharse de España, visto "el volumen y el carácter de la opinión" manifestada en los comicios, las "críticas rencorosas" que habían preparado esa opinión y "el convencimiento de que la ofuscación revolucionaria contra la Monarquía" iba principalmente contra la persona del rey (15-04-1931, p. 7).

El Debate adoptó una actitud mucho más contemporizadora, intentando nadar y guardar la ropa. Hizo hueco en la portada a dos editoriales: Nuestro homenaje a Alfonso XIII y Ante un poder constituido. En el primero llamaba al monarca destronado "gran patriota", "excelso español", "rey prudentísimo" y fiel cumplidor del deseo de

3 Víctor Olmos asegura que Juan Ignacio Luca de Tena, a la sazón director de $A B C$, visitó la tarde-noche del 13 de abril a sus colegas de otros rotativos de derechas, como el de $\mathrm{La} \mathrm{Na}$ ción, Manuel Delgado Barreto, y el de El Debate, Ángel Herrera Oria, para expresarles la conveniencia de "hacer causa común contra la República que, sin duda, iba a proclamarse". La propuesta no salió adelante porque Herrera Oria le manifestó que le era indiferente la forma de Gobierno y que sólo le preocupaba el contenido social y moral de las leyes que se dictaran, en un anticipo de la postura editorial que El Debate mantendría a partir del día siguiente (Olmos, 2002: 193-195). 
los ciudadanos, y lamentaba que se hubiera ido sin recibir el homenaje de sus leales, que formaban aún "la mayoría del pueblo español". Nada de lo anterior era óbice, sin embargo, para que El Debate acatase al Gobierno provisional de la República, porque, como Gobierno, representaba "la unidad de la patria, la paz y el orden". "Le acataremos -anunciaba- de un modo leal, activo, poniendo cuanto podamos para ayudarle en su cometido, porque no son la simpatía o la antipatía las que nos han de dictar normas de conducta"4 (15-04-1931, p. 1).

Ahora, en cambio, se mostraba muy comprensivo con el rumbo que habían tomado los acontecimientos. Señalaba que la súbita proclamación de la República era "consecuencia natural del abrumador plebiscito" del domingo anterior y se felicitaba de cómo habían transcurrido los acontecimientos: "El espectáculo de la multitud española, serena y disciplinada, dueña de sí misma y que exterioriza su entusiasmo en medio de una absoluta tranquilidad, es confortador y pone una clara nota de optimismo en un horizonte que aparecía hosco y enigmático". Recordaba Ahora que desde su primer número había defendido un régimen de orden y de sumisión a la ley, en que la violencia inútil se sustituyese por la contienda "legal fecunda". "Por creer que el régimen caído podía suministrar ese ambiente, lo hemos defendido lealmente hasta los últimos momentos", decía. "Hoy, ante el régimen nuevo, venido pacíficamente a raíz de una consulta al cuerpo electoral y por obra de ella, nuestra actitud sigue siendo la misma"5 (15-04-1931, p. 3)

El Sol, pese a su reciente mudanza de propiedad, tenía una redacción de firmes convicciones antimonárquicas, que no necesitó hacer filigranas argumentales para recibir con alegría al nuevo régimen, aunque no por ello dejó de formularle algunas advertencias. Bajo el título Orden republicano, un editorial en la primera página se felicitaba de que España tuviera ante sí "un presente de fe en los destinos de la patria, que sufrían o declinación o mengua". El periódico aludía al rey con manifiesto desapego y de una forma lapidaria: "El pueblo dio a don Alfonso la investidura suprema, y es el pueblo quien se la quita. Hoy, como hace mil años, los reyes se van y las naciones se quedan [...]. Que Dios le dé destinos clementes en la adversidad, en tanto la España en que reinó se salva con la República ante el juicio final de la historia" (1504-1931, p. 1).

$4 \quad$ Según José María García Escudero, el editorial en el que El Debate mostró su acatamiento a la República estaba escrito de antemano, lo que contradice a quienes sostienen que fue decidido en el Consejo de Redacción del día 14 (Gómez Aparicio, 1981: 242-246). García Escudero señala que el diario ya se había referido antes al menos cuatro veces a la doctrina de León XIII sobre la obligación de los católicos de respetar los poderes constituidos y que lo único que hizo en la primavera de 1931 fue aplicarla a los acontecimientos del momento (García Escudero, 19831: 130-133).

5 El giro ideológico de Ahora fue un preludio del que experimentó su fundador, Luis Montiel. Pese a haber sido diputado ciervista antes de la Dictadura de Primo de Rivera, tras la caída de la Monarquía formó parte de la candidatura Apoyo a la República, que no logró ningún escaño en las Cortes constituyentes de 1931, pese a la cancha que el periódico le dio (De Juana, 1988: 39). 
El mayor despliegue de editoriales lo hizo sin duda alguna El Liberal, que reservó a ese género casi toda su portada del día 15. El artículo principal, La primera piedra en el solar libre, empezaba describiendo la inviabilidad de una renuncia del rey en el príncipe de Asturias y de un Gobierno nacional cuyo único cometido hubiera sido la convocatoria de Cortes constituyentes. Una vez que el cuerpo electoral había dicho su última palabra el domingo anterior, los líderes republicanos no podían seguir esperando "las fórmulas que ofrecieran como transacción los monárquicos". Lo único procedente era que el último Gobierno de Alfonso XIII cediera los poderes, cumpliendo así "la voluntad nacional" (15-04-1931, p. 1).

Heraldo de Madrid subrayaba que el tránsito de un régimen a otro se había desarrollado "de forma ordenada y pacífica", frente a los que pronosticaban todo tipo de violencias. "Los terribles carbonarios, los depredadores, los violadores de la propiedad, los estupradores -ironizaba- se limitan a pasear por las calles de la ciudad su entusiasmo y su júbilo, sin un incidente grave, sin una transgresión de la ley y sin que el orden público padezca". Heraldo de Madrid también justificaba la forma en que se había impuesto la República: "La ley humanizada, la voluntad popular manifiesta expresamente adquiere un valor de eficacia sobre la letra escrita, porque así lo exigen las circunstancias y porque la letra escrita ya había sido violada para contrariar la voluntad del pueblo" durante la Dictadura (15-4-1931, p. 1).

Sólo un editorial publicó La Voz el 15 de abril, titulado Orden y trabajo. En él aplaudía el comportamiento de los madrileños en las últimas jornadas y, particularmente, el día anterior. "Hemos oído de labios de periodistas extranjeros - decía- frases donde asomaba un asombro inaudito. El espectáculo sublime de la incruenta revolución hispana les parecía un sueño". Pero no había que recrearse en lo conseguido: "Es necesario que, pasadas las horas de emoción y transporte, todos y cada uno volvamos a la cotidiana tarea. La República es orden, paz y trabajo, dentro de la libertad garantizada por las leyes. Que nadie lo olvide. Nos aguarda una labor gigantesca" (15-04-1931, p. 1).

\section{Conclusiones}

- La división entre periódicos monárquicos y antidinásticos se acentuó tras la dimisión del general Primo de Rivera el 28 de enero de 1930. ABC y El Debate (Ahora no nació hasta el 16 de diciembre) se limitaron a pedir el restablecimiento de la legalidad que llevaba casi siete años en suspenso. El Sol, El Liberal, Heraldo de Madrid y La Voz, por su parte, consideraban imprescindible la apertura de un proceso constituyente en el que los españoles pudieran pronunciarse sobre la continuidad de un rey que había contemporizado con la Dictadura.

- Esta diferente manera de enfocar la salida de la crisis política (continuista la una, potencialmente rupturista la otra) quedó de manifiesto en todos los hitos del camino que condujo al país a la República en apenas quince meses, con escasas excepciones. Los dos bloques mediáticos exhibieron sus discrepancias cuando Berenguer anunció la convocatoria de Cortes ordinarias, cuando tuvo que irse repudiado por la mayor parte de las fuerzas políticas, cuando Aznar hizo público su calendario electoral y cuando lo puso en marcha. 
- Sólo hubo un punto en que coincidieron: al conceder carácter plebiscitario a las municipales del 12 de abril antes de su celebración. Conocidos los resultados, favorables para las candidaturas republicanosocialistas, las aguas volvieron por donde solían. Aunque el jovencísimo Ahora acató sin reservas el veredicto, $A B C$ y El Debate dijeron digo donde habían dicho Diego y negaron que hubiesen sido más que unas elecciones administrativas. Sus rivales, animados por el sentido del voto, redoblaron la petición de un Parlamento constituyente.

- Quizás esta obstinación explique que ni unos ni otros fuesen capaces de anticipar lo que ocurrió cuarenta y horas después del cierre de las urnas. A lo más que llegaron algunos diarios el 14 de abril fue a proclamar que España se había pronunciado contra el rey; pero ni de lejos intuyeron que el cambio de régimen pudiera operarse ese mismo día. El deterioro de la posición política de Alfonso XIII, la determinación de los líderes republicanos y el deseo del pueblo de imponer su voluntad eran sin duda mayores de lo que ellos suponían.

- Ya el 15 de abril, al verse superados por los acontecimientos, los periódicos partidarios de dar un cauce institucional al nuevo sentimiento mayoritario de la opinión pública aceptaron sin reparos los hechos consumados. No así $A B C$, que se entregó a la tarea de deslegitimar la República, mientras sus colegas monárquicos Ahora y El Debate prometían acatarla, este último de manera circunstancial y por razones puramente tácticas, como el tiempo se encargaría de demostrar.

\section{Referencias bibliográficas}

CARABIAS, Josefina (1980): Los que le llamábamos don Manuel. Barcelona, Plaza Janés.

CARR, Raymond (1970): España 1808-1939. Barcelona, Ariel.

CHECA GODOY, Antonio (1989): Prensa y partidos politicos durante la II República. Salamanca, Universidad de Salamanca.

CORTÉS CAVANILLAS, Julián (1933): La caída de Alfonso XIII. Causas y episodios. Madrid, autoedición.

DE JUANA, Jesús (1988): La posición centrista durante la República. El periódico 'Ahora', 1930-1936. Santiago de Compostela, Universidad de Santiago de Compostela.

GARCÍA ESCUDERO, José María (1983): El pensamiento de 'El Debate', un diario católico en la crisis de España, 1911-1936. Madrid, Biblioteca de Autores Cristianos.

GÓMEZ APARICIO, Pedro (1981): De la Dictadura a la Guerra Civil. Tomo IV de Historia del periodismo español. Madrid, Editorial Nacional.

HERREROS, Isabelo (2011): "La legitimidad de la República". En: Público, 16-41931, p. 11.

JULIÁ, Santos et alt. (2007): La España del siglo XX. Madrid, Marcial Pons.

MAURA, Miguel (1962): Así cayó Alfonso XIII. México, autoedición. 
OLMOS, Víctor (2002): Historia de ABC. Barcelona, Plaza Janés.

PAYNE, Stanley (1995): La primera democracia española. La Segunda República, 1931-1936. Barcelona, Paidós.

ROBINSON, Richard (1974): Los orígenes de la España de Franco. Derecha, República y revolución 1931-1936. Barcelona, Grijalbo.

SÁNCHEZ ARANDA, José Javier y BARRERA DEL BARRIO, Carlos (1992): Historia del periodismo español. Desde sus orígenes hasta 1975. Pamplona, Universidad de Navarra.

SANTAMARÍA, María Luisa; CASALS, María Jesús (2000): La opinión periodística. Argumentos y géneros para la persuasión. Madrid, Fragua.

SEOANE, María Cruz y SAIZ, María Dolores (1996): El siglo XX: 1898-1936. Volumen 3 de Historia del periodismo en España. Madrid, Alianza.

SINOVA, Justino (2006): La prensa en la Segunda República española. Historia de una libertad frustrada. Barcelona, Debate.

TOLL, Gil (2013): Heraldo de Madrid, tinta catalana para la II República española. Madrid, Renacimiento.

\section{Referencias hemerográficas}

$A B C$. "Supremacía del poder civil". 29-01-1930, p. 15.

$A B C$. "Ante la nueva situación". 29-01-1930, p. 15.

$A B C$. "Deber de justicia". 29-01-1930, p. 15.

$A B C$. "La declaración del nuevo Gobierno". 20-02-1931, p. 17.

$A B C .11-04-1931$, p. 25.

$A B C$. "Grave situación política". 14-04-1931, p. 23.

$A B C$. 15-04-1931, p. 17.

Ahora. 10-02-1931, p. 3.

Ahora. 12-04-1931, p. 3.

Ahora, 14-04-1931, p. 3.

Ahora, 15-04-1931, p. 3.

El Debate. "Al término de una dictadura". 29-01-1930, p. 1.

El Debate. "Declaración ministerial del Gobierno". 20-02-1931, p. 1.

El Debate. "El primer triunfo". 11-04-1931, p. 1.

El Debate. "Que decidan las Cortes". 14-04-1931, p. 1.

El Debate. "Nuestro homenaje a Alfonso XIII". 15-04-1931, p. 1.

El Debate. "Ante un poder constituido". 15-04-1931, p. 1.

El Liberal. "La restitución de las libertades públicas debe ser inmediata y total". 3001-1930, p. 1.

El Liberal. "Por qué se debe votar a la República y por qué no se puede votar a la Monarquía". 11-04-1931, p. 1

El Liberal. 14-04-1931, p. 1.

El Liberal. "La primera piedra en el solar libre". 15-04-1931, p. 1. 
El Liberal. “AAbajo los Borbones!” 15-04-1931, p. 1.

El Liberal. “Adiós!” 15-04-1931, p. 1.

El Liberal. "Cómo nace la Segunda República española" 15-04-1931, p. 1.

El Sol. "La crisis política". 30-01-1930, p. 1.

El Sol. "El error Berenguer". 15-11-1930, p. 1.

El Sol. "Ante las próximas Cortes". 10-02-1931, p. 1.

El Sol. "La declaración ministerial". 21-02-1931, p. 1.

El Sol. "Veredicto". 14-04-1931, p. 1.

El Sol. "Orden republicano". 15-04-1931, p. 1.

Heraldo de Madrid. "Hay que fijar posiciones". 31-01-1930, p. 1.

Heraldo de Madrid. "Hay que salir del laberinto creado por la Dictadura" 10-02-1931, p. 1.

Heraldo de Madrid. "La tremenda lección”. 13-04-1931, p. 1.

Heraldo de Madrid. "Una lección de civilidad". 15-04-1931, p. 1.

La Voz. "Esperando hechos". 30-01-1930, p. 1.

La Voz. 10-02-1931, p. 1.

La Voz. “¡Cúmplase la voluntad nacional!” 11-04-1931, p. 1.

La Voz, 13-04-1931, p. 1.

La Voz. "Orden y trabajo". 15-04-1931, p. 1. 